\title{
Bibliography
}

\section{Abbreviations used in bibliography and chapter notes}

BLPES British Library of Political and Economic Science, London School of Economics

BPL Birmingham Public Library

BRO Bristol Record Office

ECRO Essex County Record Office, Colchester

HLRO House of Lords Record Office, Westminster

LMA London Metropolitan Archive

LPA Labour Party Archive, Manchester

MLSL Manchester Local Studies Library

MRC Modern Records Centre, University of Warwick

NLS National Library of Scotland, Edinburgh

NLW National Library of Wales, Aberystwyth

PRO Public Record Office, Kew

SLSL Southwark Local Studies Library

WCML Working Class Movement Library, Salford

WYA West Yorkshire Archives, Bradford

\section{Official records}

Government records (PRO)

AT 35

BN 29

BT 298

CAB 128, 129, 130, 134, 151, 152, 165

ED 188, 207

HLG 120, 131, 136

HO 221, 223, 291, 328, 344, 376, 389

LAB 8, 10, 28, 43, 111

MT 87

PREM 13
Department of Local Government and Regional Planning

Ministry of Health

Board of Trade

Cabinet Office

Ministry of Education

Ministry of Housing and Local

Government

Home Office

Ministry of Labour

Ministry of Transport

Prime Minister's Office 


\section{Official publications}

Hansard

Report of a Court of Inquiry under Sir Jack Stamp into a dispute concerning sewing machinists employed by the Ford Motor Company Limited (1968, Cmnd 3749)

\section{Labour Party records}

National records (LPA)

Discrimination Against Women Study Group papers

Industrial Democracy Working Party papers

National Executive Committee minutes

Campaign Sub-committee minutes

Commonwealth Sub-committee minutes

Home Policy Sub-committee minutes

National Labour Women's Advisory Committee minutes

Organisation Sub-committee minutes

Publicity and Political Education Sub-committee minutes

Regional and Local Government Advisory Committee minutes

Youth Sub-committee minutes

Race Relations and Immigration Collection

Race Relations Study Group papers

Study Group on Education papers

Study Group on Immigration papers

Youth Commission papers

\section{Regional records}

East Midlands, MRC

Eastern, ECRO

London/Greater London, LMA

Scotland, Mitchell Library, Glasgow

South West, BRO

Wales, NLW

West Midlands, MRC

\section{Borough/city records}

Birmingham Borough, BPL

Cardiff City, NLW

City of Bradford, WYA

Coventry Borough, MRC

\section{Constituency records}

Ashton-under-Lyne, Tameside Local Studies Library

Bedford, BLPES

Bermondsey, SLSL

Bethnal Green, Bancroft Library, Mile End 
Birmingham Northfield, BPL

Bradford East, WYA

Brecon and Radnor, NLW

Bristol North West, BRO

Bristol South East, BRO

Bristol West, BRO

Brixton, Lambeth Archives

Cardiff South East, NLW

Carmarthen, NLW

Chigwell and Ongar, ECRO

Clapham, Lambeth Archives

Coventry North, MRC

Dulwich, SLSL

Edinburgh South, NLS

Glasgow Maryhill, Mitchell Library, Glasgow

Halifax, Calderdale Archives, Halifax

Handsworth, MRC

Ilford South, LMA

Leith, NLS

Maldon, ECRO

Merioneth, NLW

Merton and Morden, BLPES

Nelson and Colne, WCML

North Kensington, BLPES

Norwood, LMA

Poplar, Bancroft Library, Mile End

Rugby, MRC

Salford East, WCML

Salford West, Salford Archives

Selly Oak, MRC

Shoreditch and Finsbury, Hackney Archives

Southall, LMA

St Marylebone, Westminster Archives

Stockport Central, Stockport Local Heritage Library

Toxteth, Merseyside Records Office, Liverpool

Warwick and Leamington, MRC

\section{Ward records}

Ardwick, MLSL

Newton Heath, MLSL

Labour-related organisation records

British-Asian Overseas Fellowship papers, LPA

Edinburgh Fabian Society papers, NLS

Socialist Vanguard Group papers, MRC

Tribune Group papers, LPA 
National Labour Party publications (LPA)

Reports of the annual conferences of the Labour Party

Reports of the national conferences of Labour women

Challenge to Britain (1953)

Personal Freedom (1956)

Take It From Here (1956)

Towards Equality (1956)

Hi! (1958)

Racial Discrimination (1958)

The Future Labour Offers You (1958)

Britain Belongs to You (1959)

Housewives' Choice (1959)

The Britain We Want (1959)

The Younger Generation. Report of the Labour Party Youth Commission (1959)

Let's Go! (1960)

Is This a Portrait of You? (1961)

Science and the Future of Britain (1961)

Signposts for the Sixties (1961)

The Integration of Immigrants (1962)

'Let's Go' Campaign Guide (1963)

Let's Have a Party That Will Get Things Done (1963)

Let's Go with Labour for the New Britain (1964)

Vote for Them (1964)

Don't Let Men Make All the Decisions! (1965)

Report of the Port Transport Study Group (1966)

Time for Decision (1966)

Industrial Democracy (1967)

Race Relations (1967)

Discrimination Against Women (1968)

Progress and Change (1968)

Agenda for a Generation (1969)

Now Britain's Strong Let's Make It a Great Place to Live In (1970)

Youth Voice (1970)

Women and the Labour Party (1971)

Regional Labour Party publications (LPA)

Labour Party Scottish Council, Report of the Executive Committee to the 52nd Annual Conference (Glasgow, 1967)

Labour Party Scottish Council, Report of the Executive Committee to the 53rd Annual Conference (Glasgow, 1968)

Labour Party Scottish Council, Report of the Executive Committee to the 54th Annual Conference (Glasgow, 1969)

Labour Party Scottish Council, Scottish Government. Interim Report (Glasgow, 1969)

Labour Party Scottish Council, Special Report on Scottish Government (Glasgow, 1958)

Welsh Regional Council of Labour, Labour's Policy for Wales (Cardiff, 1954) 
National Labour periodicals (LPA)

Focus

Labour Organiser

Labour Woman

New Advance

Young Socialist

\section{Local Labour periodicals}

Abingdon Labour Party Constituency Digest, LPA

Bagshot and Egham Clarion, LPA

Barons Court Citizen, LPA

Chelsea Labour News, Greater London Region papers

Contact, Warwick and Leamington CLP papers

East Ham South Citizen, LPA

Huddersfield Citizen, LPA

King's Left, Greater London Region papers

Labour Life, St Marylebone CLP papers

Labour News (up to 1962 London News), London Region papers

Labour News. Journal of Yardley Constituency Labour Party, West Midlands Region papers

Leeds Weekly Citizen, Charles Pannell papers

London News (after 1962 Labour News), London Region papers

News-Sheet, South West Region papers

North Kensington Labour Questionmaster, North Kensington CLP papers

Richmond and Barnes Clarion, LPA

Romford, Hornchurch and Brentwood Labour Voice, LPA

Warrington and District Labour News, Warrington Local Studies Library

\section{Labour-inclined periodicals}

Focus, BLPES

Forward, LPA

Socialist Commentary, LPA

Tribune, LPA

\section{Personal papers}

George Brown, Bodleian Library, Oxford

Frank Cousins, MRC

Anthony Crosland, BLPES

Maurice Edelman, MRC

Bob Edwards, LPA

Ron Evans, NLW

Anthony Greenwood, Bodleian Library

James Griffiths, NLW

Judith Hart, LPA

Deian Hopkin, NLW

Emrys Hughes, NLS 
Hugh Jenkins, BLPES

Brynmor John, NLW

George Lawson, NLS

John P. Mackintosh, NLS

Ian Mikardo/Jo Richardson, LPA

Charles Pannell, HLRO

Morgan Phillips, LPA

Cliff Protheroe, NLW

J. W. Raisin, LMA

Baron Shackleton, HLRO

Edgar Simpkins, BLPES

Reginald Sorenson, HLRO

Frank Soskice, HLRO

Eirene White, NLW

Arthur Woodburn, NLS

\section{Other parties' records}

Conservative Party Archive, Bodleian Library

General elections, 1959-70 files

Immigration, 1958-60, 1967-72 files

Women, 1946-73, 1968 files

Youth, 1960-75, 1966-73 files

Wood Green and Lower Tottenham Conservative Association, LMA

Scottish National Party, NLS

\section{Other archives}

Tom Harrisson Mass-Observation Archive, Beveridge Social Services Survey, University of Sussex

\section{Autobiographies, memoirs and diaries}

The place of publication is London unless otherwise specified.

Benn, T., Out of the Wilderness. Diaries, 1963-67 (1987)

Benn, T., Office Without Power. Diaries, 1968-72 (1988)

Benn, T., Years of Hope. Diaries, Papers and Letters 1940-1962 (1994)

Callaghan, J., Time and Chance (1987)

Castle, B., The Castle Diaries, 1964-1976 (1990)

Castle, B., Fighting All The Way (1993)

Colquhoun, M., A Woman in the House (Brighton, 1980)

Crossman, R., The Diaries of a Cabinet Minister. Volume I (1975)

Crossman, R., The Diaries of a Cabinet Minister. Volume II (1977)

Crossman, R., The Diaries of Cabinet Minister. Volume III (1977)

Jones, J., Union Man (1986) 
Manning, L., A Life for Education (1970)

Morgan, J. (ed.), The Backbench Diaries of Richard Crossman (1981)

Owen, D., Time to Declare (Harmondsworth, 1992)

Pimlott, B. (ed.), The Political Diary of Hugh Dalton, 1918-40, 1945-50 (1986)

Rowbotham, S., Promise of a Dream. Remembering the Sixties (Harmondsworth, 2000)

Short, E., Whip to Wilson (1989)

Smith, T. D., An Autobiography (Newcastle upon Tyne, 1970)

Williams, M., Inside Number 10 (1975)

Wilson, H., The Labour Government, 1964-70 (Harmondsworth, 1971)

Wilson, H., The Governance of Britain (1977)

\section{Contemporary sources}

Abrams, M., The Teenage Consumer (1959)

Abrams, M., 'Opinion polls and party propaganda', Public Opinion Quarterly, 28:1 (1964)

Abrams, M., R. Rose, and R. Hinden, Must Labour Lose? (Harmondsworth, 1960)

Abrams, P. and A. Little, 'The young activist in British politics', British Journal of Sociology, 16:4 (1965)

Albu, A., 'The organisation of industry', in R. H. S. Crossman (ed.), New Fabian Essays (1952)

Alexander, A. and A. Watkins, The Making of the Prime Minister 1970 (1970)

Ali, T., 'The extra-parliamentary opposition', in T. Ali (ed.), New Revolutionaries. Left Opposition (1969)

Almond, G. A. and S. Verba, The Civic Culture. Political Attitudes and Democracy in Five Nations (Princeton, 1963)

Anderson, P., 'The left in the fifties', New Left Review, 29 (1965)

Arblaster, A., 'Student militancy and the collapse of reformism', in R. Miliband and J. Saville (eds), Socialist Register 1970 (1970)

Arblaster, A., 'Participation: context and conflict', in G. Parry (ed.), Participation in Politics (Manchester, 1972)

Banton, M., White and Coloured. The Behaviour of British People Towards Coloured Immigrants (New Brunswick, 1960)

Barker, A., 'Participation in politics', in B. Lapping and G. Radice (eds), More Power to the People. Young Fabian Essays on Democracy in Britain (1968)

Bealey, F., J. Blondel and W. P. McCann, Constituency Politics (1965)

Benney, M., A. P. Gray and R. H. Pear, How People Vote. A Study of Electoral Behaviour in Greenwich (1956)

Bevan, A., In Place of Fear (1952)

Bing, I., 'New approaches to democracy', in I. Bing (ed.), 'The Labour Party. An organisational study', Fabian Tract, 407 (1971)

Birch, A.,H., Small Town Politics (Oxford, 1959)

Blackburn, R. and A. Cockburn (eds), The Incompatibles: Trade Union Militancy and the Consensus (Harmondsworth, 1967)

Blackstone, T., K. Gales, R. Hadley and W. Lewis, Students in Conflict. LSE in 1967 (1970)

Blythe, R., Akenfield (Harmondsworth, 1969)

Bochel, J. M., 'Activists in the Conservative and Labour parties. A study of ward secretaries in Manchester', MA thesis, University of Manchester (1965)

Booker, C., The Neophiliacs (1969) 
Budge, I. and D. W. Urwin, Scottish Political Behaviour (1966)

Butler, D. and A. King, The British General Election of 1964 (1965)

Butler, D. and A. King, The British General Election of 1966 (1966)

Butler, D. and M. Pinto-Duschinsky, The British General Election of 1970 (1971)

Butler, D. and R. Rose, The British General Election of 1959 (1960)

Butler, D. and D. Stokes, Political Change in Britain (Harmondsworth, 1971)

Coates, K., 'Democracy and workers' control', in P. Anderson (ed.), Towards Socialism (1965)

Coates, K., The Crisis of British Socialism (Nottingham, 1971)

Coates, K. and R. Silburn, Poverty. The Forgotten Englishman (Harmondsworth, 1970)

Coates, K. and T. Topham, 'The Labour Party's plans for industrial democracy', Institute for Workers' Control Pamphlet No. 5 (Nottingham, 1968)

Crane, P., 'What's in a party image?', Political Quarterly, 30:3 (1959)

Crewe, I., A. Fox and N. Day, The British Electorate 1963-1992 (Cambridge, 1995)

Crosland, C. A. R., 'The transition from capitalism', in R. H. S. Crossman (ed.), New Fabian Essays (1952)

Crosland, C. A. R., The Future of Socialism (1956)

Crosland, C. A. R., The Conservative Enemy (1962)

Crosland, A., 'A social democratic Britain', Fabian Tract, 404 (1970)

Crosland, A., Socialism Now (1974)

Crossman, R. H. S., Planning for Freedom (1965)

Dennis, N., F. Henriques and C. Slaughter, Coal is Our Life (1969)

Donnison, D. V. and D. E. G. Plowman, 'The functions of local Labour parties', Political Studies, 2:3 (1954)

Eadie, A. and J. Sillars, Don't Butcher Scotland's Future (Glasgow, 1969)

Edmonds, J., 'The worker', in B. Lapping and G. Radice (eds), More Power to the People (1968)

Fienburgh, W. and the Manchester Fabian Society, 'Put policy on the agenda', Fabian Journal, February 1952

Foot, M., 'Credo of the Labour left - interview', New Left Review, 49 (1968)

Foot, P., 'The seamen's struggle', in R. Blackburn and A, Cockburn (eds), The Incompatibles: Trade Union Militancy and the Consensus (Harmondsworth, 1967)

Fyvel, T. R., The Troublemakers. Rebellious Youth in an Affluent Society (New York, 1964)

Gaitskell, H., 'Socialism and nationalisation', Fabian Tract, 300 (1956)

Gaitskell, H., 'The economic aims of the Labour party', Political Quarterly, 26 (1956)

Gallup, G. H. The Gallup International Public Opinion Polls. Great Britain, 193775. Volume I (New York, 1976)

Glass, R., Newcomers. The West Indians in London (1960)

Goldthorpe, J. H., D. Lockwood, F. Bechhofer and J. Platt, The Affluent Worker: Industrial Attitudes and Behaviour (Cambridge, 1968)

Goldthorpe, J. H., D. Lockwood, F. Bechhofer and J. Platt, The Affluent Worker in the Class Structure (Cambridge, 1969)

Gould, J., “Riverside”: a Labour constituency, Fabian Journal, November 1954

Griffiths, J. A. G., et al., Coloured Immigrants in Britain (Oxford, 1960)

Griffiths, P., A Question of Colour? (1966)

Hamilton, M. A., The Labour Party Today (1939)

Harrisson, T., Britain Revisited (1961)

Hill, C. S., How Colour Prejudiced Is Britain? (1965)

Hill, D. M., Participating in Local Affairs (Harmondsworth, 1970)

Hoggart, R., The Uses of Literacy (Harmondsworth, 1958) 
Hoggart, R., Speaking to Each Other. Volume I (Harmondsworth, 1970)

Institute for Workers' Control, Report of the 5th National Conference on Workers' Control and Democracy (Nottingham, 1967)

Institute of Race Relations, Colour and Immigration in the United Kingdom, 1968 (1968)

Jackson, B., Working Class Community (Harmondsworth, 1972)

Janosik, E. G., Constituency Labour Parties in Britain (1968)

Jay, D., The Socialist Case (1947)

Jay, D., Socialism in the New Society (1962)

Jenkins, H., Rank and File (1980)

Jenkins, H., R. Lewis, G. Southgate and W. Wolfgang, 'The red sixties', Victory for Socialism Pamphlet (1957)

Jenkins, H. and W. Wolfgang, 'Tho' cowards flinch', Victory for Socialism Pamphlet (1956)

Jenkins, R., The Labour Case (Harmondsworth, 1959)

Jenkins, R., Essays and Speeches (1967)

Jones, G. S., 'The meaning of the student revolt', in A. Cockburn and R. Blackburn, Student Power (Harmondsworth, 1969)

Jones, J., 'The right to participate - key to industrial progress', TGWU Pamphlet (1970)

Jupp, J., 'The discontents of youth', Political Quarterly, 40 (1969)

Kornhauser, W., The Politics of Mass Society (1960)

Lane, T. and K. Roberts, Strike at Pilkingtons (1971)

Levin, B., The Pendulum Years (1970)

Mayhew, C., Party Games (1969)

McKitterick, T. E. M., 'The membership of the party', Political Quarterly, 31 (1960)

Mikardo, I., 'Trade unions in a full employment economy', in R. H. S. Crossman (ed.), New Fabian Essays (1952)

New Bristol Group, Output 1962/63 (Bristol, 1963)

New Bristol Group, Output 1963/64 (Bristol, 1964)

New Bristol Group, Output 3 (Bristol, 1966)

Nichols, T. and P. Armstrong, Workers Divided. A Study in Shopfloor Politics (1976)

Parkin, F., Middle Class Radicalism (Manchester, 1968)

Pateman, C., Participation and Democratic Theory (Cambridge, 1970)

Pearson, J. and G. Turner, The Persuasion Industry (1965)

Pelling, H., 'Then and now: popular attitudes since 1945', in his Popular Politics and Society in Late Victorian Britain (1968)

Rex, J. and R. Moore, Race, Community and Conflict. A Study of Sparkbrook (Oxford, 1967)

Rose, E. J. B., Colour and Citizenship (1969)

Rose, P., 'Manchester Left Club on youth', New Left Review, 1 (1960)

Rose, R., Influencing Voters (1967)

Rowbotham, S., 'The beginnings of women's liberation in Britain', in M. Wandor (ed.), The Body Politic. Women's Liberation in Britain (1972)

Rowland, C., 'Labour publicity', Political Quarterly, $31: 3$ (1960)

Rowntree, S. and G. R. Lavers, Poverty and the Welfare State (1951)

Rustin, M., 'Young Socialists', New Left Review, 9 (1961)

Samuel, R., 'Dr. Abrams and the end of politics', New Left Review, 5 (1960)

Scanlon, H., 'The role of militancy', New Left Review, 46 (1967)

Scanlon, H., 'The way forward for workers' control', Institute for Workers' Control Pamphlet No. 1 (Nottingham, 1968)

Sharpe, L. J., 'Brixton', in N. Deakin (ed.), Colour and the British Electorate 1964 (1965) 
Sherman, A., 'Deptford', in N. Deakin (ed.), Colour and the British Electorate 1964 (1965)

Shils, E. and M. Young, 'The meaning of the Coronation', Sociological Review, 1 (1953)

Shore, P., The Real Nature of Conservatism (1952)

Spiers, M., 'Bradford', in N. Deakin (ed.), Colour and the British Electorate 1964 (1965)

Thompson, E. P. (ed.), Warwick University Ltd (Harmondsworth, 1970)

Titmus, R. M., Income Distribution and Social Change (1962)

Trenaman, J. and D. McQuail, Television and the Political Image (1961)

Watkins, A., 'Labour in power', in G. Kaufman (ed.), The Left (1966)

West, R., 'Campaign journal', Encounter, December 1964

Westergaard, J. H., 'Sociology: the myth of classlessness', in R. Blackburn (ed.), Ideology in Social Science (1972)

White, E., 'Workers' control?', Fabian Society Challenge Series Pamphlet No. 4 (1949)

Williams, R. (ed.), May Day Manifesto 1968 (Harmondsworth, 1968)

Wilmott, P., The Evolution of a Community (1963)

Willmott, P., Adolescent Boys of East London (Harmondsworth, 1969)

Wilson, H., The New Britain (Harmondsworth, 1964)

Woolcott, D., 'Southall', in N. Deakin (ed.), Colour and the British Electorate 1964 (1965)

Young, M. and P. Wilmott, Family and Kinship in East London (Harmondsworth, 1957)

Young, M. and P. Wilmott, The Symmetrical Family (Harmondsworth, 1975)

Zweig, F., The Worker in an Affluent Society (1961)

Zweig, F., The Student in the Age of Anxiety (1963)

\section{Secondary sources}

Almond, G. A., 'The intellectual history of the civic culture concept', in G. A. Almond and S. Verba (eds), The Civic Culture Revisited (Boston, 1980)

Bain, G. S. and R. Price, 'Union growth: dimensions, determinants and density', in G. S. Bain (ed.), Industrial Relations in Britain (Oxford, 1983)

Ballaster, R., M. Beetham, E. Fraser and S. Hebra, Women's Worlds. Ideology, Femininity and the Woman's Magazine (1991)

Barrow, L. and I. Bullock, Democratic Ideas and the British Labour Movement, 18801914 (Cambridge, 1996)

Baucher, D., The Feminist Challenge. The Movement for Women's Liberation in Britain and the USA (1983)

Beer, S. H., Britain Against Itself (1982)

Beer, S. H., 'Why study British politics?', British Politics Group Newsletter, 100 (2000)

Black, A. and S. Brooke, 'The Labour Party, women, and the problem of gender, 1951-1966', Journal of British Studies, 36:4 (1997)

Black, L., The Political Culture of the Left in Affluent Britain, 1951-64 (2003)

Black, L., "What kind of people are you?" Labour, the people and the new political history', in J. Callaghan, S. Fielding and S. Ludlam (eds), Interpreting the Labour Party: Approaches to Labour Politics and History (Manchester, 2004)

Bourke, J., Working-Class Cultures in Britain, 1890-1960 (1994)

Brivati, B., Hugh Gaitskell (1996)

Brooke, S., 'The Conservative Party, immigration and national identity, 19481968', in M. Francis and I. Zweiniger-Bargielowska (eds), The Conservatives and British Society, 1880-1990 (Cardiff, 1996) 
Butler, D., British General Elections Since 1945 (Oxford, 1989)

Byrne, P., 'The politics of the women's movement', Parliamentary Affairs, 49:1 (1996)

Campbell, J., Edward Heath. A Biography (1993)

Capet, A., 'Rediscovering the "rediscovery of poverty" in the 1950s', paper presented to the conference 'Affluent Britain?', Bristol University, May 2002

Cesarani, D. (ed.), The Making of Modern Anglo-Jewry (Oxford, 1990)

Cheetham, J., 'Immigration', in A. H. Halsey (ed.), Trends in British Society Since 1900 (1972)

Clapson, M., Invincible Green Suburbs, Brave New Towns (Manchester, 1998)

Clarke, P., 'The social democratic theory of the class struggle', in J. Winter (ed.), The Working Class in Modern British History (Cambridge, 1983)

Clarke, P. F., Liberals and Social Democrats (Cambridge, 1978)

Coates, D., 'Labour governments: old constraints and new parameters', New Left Review, 291 (1996)

Coates, D. and L. Panitch, 'The continuing relevance of the Milibandian perspective', in J. Callaghan, S. Fielding and S. Ludlam (eds), Interpreting the Labour Party: Approaches to Labour Politics and History (Manchester, 2004)

Collette, C., "'Daughters of the Newer Eve": The labour movement and women', in J. Fyrth (ed.), Labour's Promised Land? (1995)

Collette, C., 'Questions of gender: Labour and women', in B. Brivati and R. Heffernan (eds), The Labour Party. A Centenary History (2000)

Conekin, B., F. Mort and C. Waters, 'Introduction', in B. Conekin, F. Mort and C. Waters (eds), Moments of Modernity. Reconstructing Britain, 1945-1964 (1999)

Creear, M., 'Gender, class and political activism in the North West: Labour's women's organisation in the 1970s', North West Labour History Journal, 27 (2002)

Crosland, S., Tony Crosland (1982)

Currie, R., Industrial Politics (Oxford, 1979)

Davies, A. and S. Fielding (eds), Workers' Worlds. Cultures and Communities in Manchester and Salford, 1880-1939 (Manchester, 1992)

Davis, J., 'Rents and race in 1960s London: new light on Rachmanism', Twentieth Century British History, 12:1 (2001)

Dresser, M., 'The colour bar in Bristol', in R. Samuel (ed.), Patriotism. Volume I (1989)

Fielding, S., “Don't know and don't care”: popular political attitudes in Labour's Britain, 1945-51', in N. Tiratsoo (ed.), The Attlee Years (1991)

Fielding, S., 'Labourism in the 1940s', Twentieth Century British History, 3:2 (1992)

Fielding, S., Class and Ethnicity. Irish Catholics in England, 1880-1939 (Buckingham, 1993)

Fielding, S., "White heat" and white collars: the evolution of "Wilsonism", in R. Coopey, S. Fielding and N. Tiratsoo (eds), The Wilson Governments, 1964 $70(1993)$

Fielding, S., "Brotherhood and the brothers: responses to "coloured" immigration in the British Labour party, c. 1951-65', Journal of Political Ideologies, 3:1 (1998)

Fielding, S., “'Labourism” and the British Labour Party', in the Collection de l'Ecole Francaise de Rome - 267, Les Familles Politiques en Europe Occidentale au XXe Siecle (Rome, 2000)

Fielding, S., 'The Labour party and the recruitment of the young, 1945-70', in G. Orsina and G. Quagliariello (eds), La Formazione della classe politica in Europa (1945-1956) (Rome, 2000)

Fielding, S., "The "penny farthing machine" revisited: Labour Party members and participation in the 1950s and 1960s', in C. Pierson and S. Tormey (eds), Politics at the Edge (2000) 
Fielding, S., 'Activists against "affluence": Labour party culture during the "Golden Age", c. 1950-1970', Journal of British Studies, 40:2 (2001)

Fielding, S., “But westward, look, the land is bright!" Labour's revisionists and the imagining of America, c. 1945-64', in J. Hollowell (ed.), Twentieth-Century Anglo-American Relations (2001)

Fielding, S., "“New" Labour and the "new" labour history', Mitteilungsblatt des Instituts fur soziale Bewegungen, 28 (2002)

Fielding, S., P. Thompson and N. Tiratsoo, 'England Arise!' The Labour Party and Popular Politics in 1940s Britain (Manchester, 1995)

Finch, J. and P. Summerfield, 'Social reconstruction and the emergence of companionate marriage, 1945-59', in D. Clark (ed.), Marriage, Domestic Life and Social Change (1991)

Foote, G., The Labour Party's Political Thought (1997)

Fowler, D., The First Teenagers. The Lifestyle of Young Wage-Earners in Interwar Britain (1995)

Francis, M., Ideas and Policies Under Labour 1945-1951 (Manchester, 1997)

Francis, M., 'Labour and gender', in D. Tanner, P. Thane and N. Tiratsoo (eds), Labour's First Century (Cambridge, 2000)

Francis, M. and I. Zweiniger-Bargielowska (eds), The Conservatives and British Society, 1880-1990 (Cardiff, 1996)

Fryer, P., Staying Power. The History of Black People in Britain (1984)

Gallup Poll, 'Voting behaviour in Britain, 1945-1974', in R. Rose (ed.), Studies in British Politics (1976)

Giddens, A., Beyond Left and Right (Cambridge, 1994)

Gilroy, P., 'There Ain't No Black in the Union Jack'. The Cultural Politics of Race and Nation (1987)

Glennester, H., 'Education and inequality', in P. Townsend and N. Bosanquet (eds), Labour and Inequality (1972)

Goldthorpe, J. H., Social Mobility and Class Structure in Modern Britain (Oxford, 1980)

Graves, P., Labour Women: Women in British Working-Class Politics, 1918-1939 (Cambridge, 1994)

Green, E. H. H., The Crisis of Conservatism. The Politics, Economics and Ideology of the British Conservative Party, 1880-1914 (1995)

Green, E. H. H., 'The Conservative party, the state and the electorate', in J. Lawrence and M. Taylor (eds), Party, State and Society (Aldershot, 1997)

Gwyn, W. B., 'The Labour party and the threat of bureaucracy', Political Studies, $29(1971)$

Gyford, J., The Politics of Local Socialism (1985)

Hall, S. and T. Jefferson (eds), Resistance Through Rituals (1976)

Halsey, A. H., 'Higher education', in A. H. Halsey (ed.), Trends in British Society Since 1900 (1972)

Halsey, A. H., 'Government against poverty in school and community', in D. Wedderburn (ed.), Poverty, Inequality and Class Structure (Cambridge, 1974)

Halsey, A. H., Change in British Society (Oxford, 1985)

Hansen, R., Citizenship and Immigration in Post-war Britain (Oxford, 2000)

Hatton T. J. and R. E. Bailey, 'Seebohm Rowntree and the postwar poverty puzzle', Economic History Review, 53:2 (2000)

Heath, A., R. Jowell and J. Curtice, How Britain Votes (Oxford, 1985)

Heath, A., R. Jowell, J. Curtice, G. Evans, J. Field and S. Witherspoon, Understanding Political Change. The British Voter, 1964-87 (Oxford, 1991)

Heffer, S., Like the Roman. The Life of Enoch Powell (1999)

Hinton, J., '1945 and the Apathy School', History Workshop, 43 (1997) 
Hobsbawm, E., 'The Labour aristocracy in nineteenth century Britain', in his Labouring Men (1964)

Hobsbawm, E., 'The formation of British working class culture', in his Worlds of Labour (1984)

Hobsbawm, E., 'The making of the working class, 1870-1914', in his Worlds of Labour (1984)

Hobsbawm, E., Age of Extremes. The Short Twentieth Century 1914-1991 (1995)

Hollis, P., Jennie Lee. A Life (Oxford, 1997)

Holmes, C., John Bull's Island. Immigration and British Society, 1871-1971 (1988)

Horner, J., Studies in Industrial Democracy (1974)

Howard, A., Crossman. The Pursuit of Power (1990)

Howarth, D., A. J. Norval and Y. Stavrakakis (eds), Discourse Theory and Political Analysis (Manchester, 2000)

Howe, S., Anticolonialism in British Politics. The Left and the End of Empire, 19181964 (Oxford, 1993)

Inglehart, R., 'The silent revolution in Europe: intergenerational change in post-industrial societies', American Political Science Review, 65:4 (1971)

Inglehart, R., The Silent Revolution. Changing Values and Political Styles Among Western Publics (Princeton, 1977)

Jones, R. M. and I. R. Jones, 'Labour and the nation', in D. Tanner, C. Williams and D. Hopkins (eds), The Labour Party in Wales, 1900-2000 (Cardiff, 2000)

Jones, T., Remaking the Labour Party (1996)

Jones, T. K., 'Employee directors in the British Steel Corporation', in C. Balfour (ed.), Participation in Industry (1973)

Joyce, P., Realignment of the Left? A History of the Relationship Between the Liberal Democrat and Labour Parties (1999)

Katznelson, I., Black Men, White Cities. Race, Politics and Migration in the United States, 1900-30, and Britain, 1948-68 (Oxford, 1973)

Kavanagh, D., 'Political culture in Great Britain: the decline of the civic culture', in G. A. Almond and S. Verba (eds), The Civic Culture Revisited (Boston, 1980)

Keating, M., 'The Labour party in Scotland, 1951-1964', in I. Donnachie, C. Harvie and I. S. Wood (eds), Forward! Labour Politics in Scotland, 1888-1988 (Edinburgh, 1988)

Keating, M. and D. Bleiman, Labour and Scottish Nationalism (1979)

Kitschelt, H., The Transformation of European Social Democracy (Cambridge, 1994)

Kraushaar, R., 'Policy without protest: the dilemma of organising for change in Britain', in M. Harloe (ed.), New Perspectives in Urban Change and Conflict (1981)

Lancaster, B., 'Who's a real Coventry kid? Migration into 20th century Coventry', in T. Mason and B. Lancaster (eds), Life and Labour in a 20th Century City. The Experience of Coventry (Coventry, 1986)

Lawrence, J., Speaking for the People. Party, Language and Popular Politics in England, 1867-1914 (Cambridge, 1998)

Lawrence, J. and M. Taylor, 'Introduction', in J. Lawrence and M. Taylor (eds), Party, State and Society (Aldershot, 1997)

Layton-Henry, Z., 'Labour's lost youth', Journal of Contemporary History, 11 (1976) Lewis, J., 'Myrdal, Klein, "Women's two roles" and postwar feminism, 19451960', in H. L. Smith (ed.), British Feminism in the Twentieth Century (Aldershot, 1990)

Lewis, J., 'From equality to liberation: contextualising the emergence of the Women's Liberation Movement', in B. Moore-Gilbert and J. Seed (eds), Cultural Revolution? The Challenge of the Arts in the 1960s (1992)

Lindrop, F., 'Racism and the working class: strikes in support of Enoch Powell in 1968', Labour History Review, 66:1 (2001) 
Lunn, K., 'Complex encounters: trade unions, immigration and racism', in J. McIlroy, N. Fishman and A. Campbell (eds), British Trade Unions and Industrial Politics. Volume II (Aldershot, 1999)

Lyon, A., 'A Labour view', in M. Loney and M. Allen (eds), The Crisis of the Inner City (1979)

MacIntyre, S., A Proletarian Science. Marxism in Britain, 1917-1933 (Cambridge, 1980)

Marquand, D., 'Reaching for the levers', Times Literary Supplement, 11 April 1997

Marsden, D., 'Politicians, equality and comprehensives', in P. Townsend and N. Bosanquet (eds), Labour and Inequality (1972)

Marwick, A., The Sixties (Oxford, 1998)

May, J. D., 'Opinion structure of political parties: the special law of curvilinear disparity', Political Studies, 21 (1973)

Mayo, M., 'The history and early development of CDP', in R. Lees and G. Smith (eds), Action-Research in Community Development (1975)

McClymont, G., "'A squalid raffle”? Labour, affluence and the introduction of Premium Bonds, 1956', paper presented to the conference 'Affluent Britain?', Bristol University, May 2002

McHugh, D., 'A "mass" party frustrated? The development of the Labour party in Manchester, 1918-31', PhD thesis, University of Salford (2001)

McIlroy, J., 'Note on the Communist party and industrial politics', in J. McIlroy, N. Fishman and A. Campbell (eds), British Trade Unions and Industrial Politics. Volume II (Aldershot, 1999)

McIlroy, J. and A. Campbell, 'The high tide of trade unionism: mapping industrial politics, 1964-79', in J. McIlroy, N. Fishman and A. Campbell (eds), British Trade Unions and Industrial Politics. Volume II (Aldershot, 1999)

McKenzie, J. M., Propaganda and Empire. The Manipulation of British Public Opinion 1880-1960 (Manchester, 1984)

McKibbin, R., The Ideologies of Class. Social Relations in Britain, 1880-1950 (Oxford, 1991)

McKibbin, R., Classes and Cultures: England, 1918-51 (Oxford, 1998)

Miliband, R., 'Socialism and the myth of the golden past', in R. Miliband and J. Saville (eds), Socialist Register 1964 (1964)

Miliband, R., Parliamentary Socialism (1972)

Miliband, R., 'Politics and poverty', in D. Wedderburn (ed.), Poverty, Inequality and Class Structure (Cambridge, 1974)

Miliband, R., 'A state of de-subordination', British Journal of Sociology, 29:4 (1978)

Minkin, L., The Labour Party Conference (1978)

Minkin, L., The Contentious Alliance (Edinburgh, 1992)

Morgan, K. O., Rebirth of a Nation. Wales, 1880-1980 (Oxford, 1981)

Morgan, K. O., Labour in Power, 1945-1951 (Oxford, 1984)

Morgan, K. O., The People's Peace. British History 1945-1990 (Oxford, 1992)

Morgan, K. O., Callaghan. A Life (Oxford, 1997)

Mulgan, G., Politics in an Antipolitical Age (Cambridge, 1994)

Musgrove, F., Ecstacy and Holiness. Counter Culture and the Open Society (1974)

Osgerby, B., Youth in Britain Since 1945 (Oxford, 1998)

Panitch, L., Social Democracy and Industrial Militancy (Cambridge, 1976)

Panitch, L. and C. Leys, The End of Parliamentary Socialism (1997)

Parkinson, M., 'The Labour party and the organisation of secondary education', MA thesis, University of Manchester (1968)

Paul, K., Whitewashing Britain. Race and Citizenship in the Postwar Era (Ithaca, 1997)

Pearson, G., Hooligan. A History of Respectable Fears (1983) 
Pilkington, E., Beyond the Mother Country. West Indians and the Notting Hill White Riots (1988)

Pimlott, B., Wilson (1992)

Pugh, M., 'Domesticity and the decline of feminism, 1930-1950', in H. L. Smith (ed.), British Feminism in the Twentieth Century (Aldershot, 1990)

Rae, J., The Public School Revolution (1981)

Reid A. and E. Biagini (eds), Currents of Radicalism. Popular Radicalism, Organized Labour and Party Politics in Britain, 1850-1914 (Cambridge, 1991)

Reynolds, D., Rich Relations. The American Occupation of Britain, 1942-1945 (1995)

Richards, M. P. M. and B. J. Elliott, 'Sex and marriage in the 1960s and 1970s', in D. Clark (ed.), Marriage, Domestic Life and Social Change (1991)

Riddell, N., Labour in Crisis. The Second Labour Government, 1929-31 (Manchester, 1999)

Roberts, E., Women and Families. An Oral History, 1940-1970 (Oxford, 1995)

Rollett, C. and J. Parker, 'Population and family', in A. H. Halsey (ed.), Trends in British Society Since 1900 (1972)

Rubinstein, D. and B. Simon, The Evolution of the Comprehensive School (1973)

Sampson, A., Macmillan. A Study in Ambiguity (Harmondsworth, 1968)

Samuel R. and G. S. Jones, 'The Labour party and social democracy', in R. Samuel and G. S. Jones (eds), Culture, Ideology and Politics (1982)

Sassoon, D., One Hundred Years of Socialism (1997)

Schwarz, B., 'Politics and rhetoric in the age of mass culture', History Workshop Journal, 46 (1998)

Seed, J., 'Hegemony postponed: the unravelling of the culture of consensus in Britain in the 1960s', in B. Moore-Gilbert and J. Seed (eds), Cultural Revolution? The Challenge of the Arts in the 1960s (1992)

Shaw, E., Discipline and Discord in the Labour Party (Manchester, 1988)

Sinfield, A., Literature, Politics and Culture in Postwar Britain (Oxford, 1989)

Solomos, J., Race and Racism in Britain (1993)

Spencer, I., 'World War Two and the making of multiracial Britain', in P. Kirkham and D. Thoms (eds), War Culture. Social Change and Changing Experience in World War Two (1995)

Studlar, D. T., 'British public opinion, colour issues and Enoch Powell: a longitudinal analysis', British Journal of Political Science, 4:3 (1974)

Studlar, D. T., 'Policy voting in Britain: the coloured immigration issue in the 1964, 1966 and 1970 general elections', American Political Science Review, 72:1 (1978)

Tanner, D., Political Change and the Labour Party, 1900-1918 (Cambridge, 1990)

Taylor, M., 'Labour and the constitution', in D. Tanner, P. Thane and N. Tiratsoo (eds), Labour's First Century (Cambridge, 2000)

Taylor, R., 'The Labour party and CND', in R. Taylor and N. Young (eds), Campaigns for Peace. British Peace Movements in the Twentieth Century (Manchester, 1987)

Thane, P., 'Towards equal opportunities? Women in Britain since 1945', in T. Gourvish and A. O'Day (eds), Britain Since 1945 (1991)

Thompson, E. P., The Making of the English Working Class (1963)

Thompson, P., 'Labour's "Gannex conscience"? Politics and popular attitudes to the "permissive society", in R. Coopey, S. Fielding and N. Tirasoo (eds), The Wilson Governments, 1964-70 (1993)

Thorpe, A., A History of the British Labour Party (1997)

Thorpe, K., "The "juggernaught method": the 1966 state of emergency and the Wilson government's response to the seamen's strike', Twentieth Century British History, 12:4 (2001) 
Tiratsoo, N., Reconstruction, Affluence and Labour Politics. Coventry 1945-60 (1990) Tiratsoo, N., 'Popular politics, affluence and the Labour party', in A. Gorst, L. Johnman and W. S. Lucas (eds), Contemporary British History, 1931-61 (1991)

Tiratsoo, N. (ed.), The Attlee Years (1991)

Tomlinson, J., Democratic Socialism and Economic Policy (Cambridge, 1997)

Turner, J. E., Labour's Doorstep Politics in London (1978)

Vernon, J., Politics and the People. A Study in English Political Culture, c. 1815-1867 (Cambridge, 1993)

Vernon, J., 'Notes towards an introduction', in J. Vernon (ed.), Re-reading the Constitution. New Narratives in the Political History of England's Long Nineteenth Century (Cambridge, 1996)

Waters, C., British Socialists and the Politics of Popular Culture, 1884-1914 (Manchester, 1990)

Weakliem, D., 'Class consciousness and political change: voting and political attitudes in the British working class, 1964-1970', American Sociological Review, 58:3 (1993)

Weight, R., Patriots. National Identity in Britain, 1940-2000 (2002)

Whiteley, P., The Labour Party in Crisis (1983)

Wickham-Jones, M., Economic Strategy and the Labour Party (1996)

Williams, P. M., Hugh Gaitskell (Oxford, 1982)

Williams, R., The Long Revolution (Harmondsworth, 1965)

Williams, R., Keywords (1976)

Wood, F., 'Scottish Labour in government and opposition, 1964-79', in I. Donnachie, C. Harvie and I. S. Wood (eds), Forward! Labour Politics in Scotland, 1888-1988 (Edinburgh, 1988)

Wrigley, C., 'Trade unions, the government and the economy', in T. Gourvish and A. O'Day (eds), Britain Since 1945 (1991)

Yeo, S., 'A new life: the religion of socialism in Britain, 1883-1896', History Workshop Journal, 4 (1977)

Young, J., 'Britain and “LBJ's war”, 1964-68', Cold War History, 2:3 (2002)

Young, K., 'Orpington and the "Liberal revival", in C. Cook and J. Ramsden (eds), By-elections in British Politics (1973)

Young, N., An Infantile Disorder? The Crisis and Decline of the New Left (1977)

Zeigler, P., Wilson (1993)

Zweiniger-Bargielowska, I., 'Explaining the gender gap: the Conservative Party and the women's vote, 1945-1964', in M. Francis and I. ZweinigerBargielowska (eds), The Conservatives and British Society, 1880-1990 (Cardiff, 1996) 